\title{
The Association between Resistin, Leptin and Adiponectin with Obesity and Type 2 Diabetes Mellitus
}

\author{
MOHAMED T. ABD-ELREHEEM, Ph.D. ${ }^{1}$; AYMAN S. SOLIMAN, M.D. 2 ; WAFAA I RASHEED, M.D. ${ }^{3}$; \\ AMIRA M. JAWAD, M.D. ${ }^{3}$ and NOHA T. ABD-ELREHEEM, M.D. ${ }^{4}$ \\ The Department of Biochemistry, Faculty of Pharmacy, Cairo University ${ }^{1}$, Physiology Department, Faculty of Medicine, \\ Beni-Suef University 2, Medical Biochemistry Department, National Research Center ${ }^{3}$ and InernalMedicine Department, \\ Faculty of Medicine, Cairo University4, Egypt
}

\begin{abstract}
Background: Obesity is an important public health concern among all age groups in the world and is a risk to develop insulin resistance and associated metabolic diseases. Fat tissue exerts important endocrine functions, which are mediated by a complex network of various soluble factors, derived from adipocytes, called adipocytokines including tumor necrosis factor a (TNF- $\alpha$ ), Interleukin (IL) 6 , leptin, adiponectin and resistin. Some adipokines play a major role in insulin resistance and cardiovascular complications associated with obesity, especially central or visceral obesity.
\end{abstract}

Aim of Study: The aim of this study was to discover the role of leptin, adiponectin and resistin as a link between obesity and insulin resistance type 2 diabetes through assessment of their levels in normal weight, obese before and after weight reduction as well as obese diabetic subjects.

Patients and Methods: Forty-five female subjects divided into four groups, 15 subjects with normal weight-as control group (group I), 15 obese subjects (group II), 10 subjects from group II followed a weight reduction regimen for 2 months (group III) and 15 obese diabetic subjects (group VI). Serum insulin, leptin, adiponectin and resistin were measured by ELISA. Lipid profile was measured by a spectrophotometric method. Anthropometric measurements were also performed.

Results: The study showed that the obese and obese diabetic subjects have got higher serum leptin and resistin levels when compared with controls. In contrast, serum adiponectin concentration was significantly lower in obese before diet and obese diabetic subjects when compared to the control group. After weight loss, significant improvement has been observed in all parameters. The findings from bivariate correlation analysis were further explored using multiple linear regression analysis which confirmed that resistin rather than adiponectin and leptin was an important determinant of insulin resistance.

Conclusion: This study concluded that even modest weight loss can improve metabolic risk factors through modulation of some adipokines.

Correspondence to: Dr. Mohamed T. Abd-Elreheem, The Department of Biochemistry, Faculty of Pharmacy, Cairo University
Key Words: Obesity - Diabetes - Insulin resistance - Leptin - Adiponectin - Resistin.

\section{Introduction}

OBESITY is increasingly becoming an important public health concern among all age groups in most of the developed world [1]. Greater than 30\% of the United States population is obese and at risk to develop insulin resistance and associated metabolic disorders, including hypertension, hyperlipidemia, fatty liver disease, atherosclerosis, and Type 2 diabetes mellitus [2]. Obesity is a frequent concomitant of type 2 diabetes [3]. It has been estimated that not less than $90 \%$ of type 2 diabetes are overweight or obese [4]. Together with obesity, several factors are implicated in the development of type 2 diabetes, including family history, physical inactivity and inherited factors [ $\boldsymbol{s}$

Adipose tissue stores excess energy in the form of lipids and are thus able to dramatically change in size in accordance with changing metabolic needs [6]. Moreover, studies have shown that fat tissue exerts important endocrine functions which are mediated by a complex network of various soluble factors derived from adipocytes called adipocytokines [7] including tumor necrosis factor a (TNF- $\alpha$ ), Interleukin (IL) 6 , leptin, adiponectin and resistin [6]. Some adipokines play a major role in insulin resistance and cardiovascular complications associated with obesity, especially central or visceral obesity [8]

At the cellular level, obesity is not solely a pathology of adipocytes as there are other cell types within adipose tissue that participate as well. In fact, the presence of infiltrating macrophages in adipose tissue makes obesity comparable to a 
low-grade chronic inflammation with links between adipose cells and the immune system. At present comprehension of these concepts is essential for a better understanding of the pathophysiological mechanisms of insulin resistance and type 2 diabetes [9]

Leptin was one of the first adipocytokines identified, and immediately has drawn substantial research attention [4]. The discovery of leptin in 1994 has provided a major new piece in the puzzle of obesity, as it has been found that its level was directly related to the quantity of body fat [10] Leptin is a $16 \mathrm{kDa}$ non-glycosylated protein secreted in direct proportion to adipose tissue mass as well as nutritional status. Plasma leptin concentrations positively correlate with subcutaneous rather than intra-abdominal fat tissue mass [11]. Leptin exerts an inhibitory effect on food intake and increases energy expenditure through thermogenesis and physical activity [12]. The idea of leptin as an insulin sensitizing hormone and leptin deficiency or resistance as a potential link between obesity and diabetes has been reviewed recently [13].

The discovery of adiponectin (ApN) occurred at about the same time as the discovery of leptin (1995/1996), but it did not receive major attention in the scientific community for the next few years until its markedly protective role in the pathogenesis of obesity-related disorders was acknowledged. Adiponectin is a $30-\mathrm{kDa}$ adipocyte complementrelated protein [12]. Prospective studies in humans have shown that increased plasma concentrations of ApN was strongly and independently associated with reduced risk of type 2 diabetes [14]. In contrast to most other adipokines, circulating ApN was negatively correlated with body mass index (BMI) [15] and was markedly decreased in obese subjects and in patients with type 2 diabetes [16]

Resistin is a $12.5-\mathrm{kDa}$ cysteine-rich peptide that belongs to a family of resistin-like molecules with distinct expression patterns and biological effects [17]. Resistin is primarily secreted from mature adipocytes in rodents whereas in humans it is expressed primarily from adipose infiltrating macrophages [5]. It was suggested that resistin might link obesity with insulin resistance and diabetes [4] . In humans, the role of resistin in insulin resistance remains controversial. Increased circulating levels of resistin are associated with incidence of obesity, insulin resistance, and inflammation [18]. Most mouse studies, but not all, support the notion that resistin is an adipokine regulator of insulin action. However, most human studies show an entirely different picture [19].

\section{Subjects and Methods}

\section{I- Subjects:}

The current study was carried out on 45 female subjects recruited from obesity and internal medicine outpatient clinics of the National Research Centre. Their ages ranged from $18-45$ years old. This study was done during the year 2017 and was approved by the ethics committee of the National Research Centre and all subjects gave their written informed consent prior to entering this study.

Subjects were divided into four groups:

- Group (I); Control group: 15 Normal weight subjects with BMI of $22.21 \pm 1.89$.

- Group II: 15 obese subjects with BMI of $34.07 \pm$ 3.81.

- Group III: 10 obese subjects of group II reevaluated after 2 months of dietary intervention in the form of caloric intake restriction to less than their usual intake by $(500 \mathrm{kcal})$ and exercise program in the form of physical activity of moderate intensity, such as brisk walking. The mean BMI was $28.72 \pm 2.42$.

- Group IV: 15 obese diabetic subjects with BMI of $35.27 \pm 2.28$.

II- Methods:

a-Anthropometry:

Anthropometric measurements, including height, weight, waist circumference (WC) and hip circumference (HC) were performed. BMI was calculated as weight in $(\mathrm{kg})$ divided by height in meters squared $\left(\mathrm{m}^{2}\right)$. Waist-to-hip ratio (WHR) was also calculated as waist circumference (WC) divided by hip circumference (HC). BMI is used to reflect the total body fat while (WC) and WHR an indirect measurements of body fat centralization.

\section{b-Biochemical assays:}

Morning blood samples were collected after 12 hours of fasting; 8ml Venous blood samples were withdrawn from each participant in the study. Two milliliters of blood were added to sodium fluoride and centrifuged. The plasma was separated and used for determination of fasting plasma glucose (FPG) by glucose oxidase method [20] using the kit supplied by STANBIO laboratory. Six milliliters of blood were left to clot then the serum was obtained by centrifugation and divided into several aliquots and stored at $-20^{\circ} \mathrm{C}$ until used.

For quantitative determination of serum insulin, leptin, adiponectin and resistin, an enzyme-linked immunosorbent assay (ELISA) was used. Serum Insulin and leptin were measured according to 
$[21,22]$ respectively and the kits were provided from (DRG, USA). Adiponectin was assayed according to [23] and the kit was supplied from (Orgenium Laboratories, Finland). Resistin was measured according to [24] with a kit supplied from (Biovendor, Czech Republic). Insulin resistance was calculated by HOMA-IR (Homeostatic Model Assessment for Insulin Resistance), as fasting insulin ( $\mathrm{IU} / \mathrm{ml}) \mathrm{X}$ fasting glucose $(\mathrm{mmol} / \mathrm{L}) / 22.5$. [25] Total cholesterol [26], HDL-cholesterol [27], and triglycerides [28] were also, determined in serum using the kits supplied by Pointe Scientific Inc. Serum LDL-cholesterol was calculated using Friedewald equation [29].

\section{Exclusion criteria:}

Insulin dependent type 1 diabetes, concomitant disturbances of liver and thyroid, renal insufficiency and chronic inflammatory diseases.

\section{Statistical analysis:}

All statistical analysis was done using the statistical package for the social science (SPSS software) on a personal computer. All numeric variables were expressed as a mean \pm standard deviation (SD). The independent-sample $t$-test was used to compare means. Pearson's correlation coefficient was obtained and a $p$-value $<0.05$ was considered as statistically significant. Step wise multiple regression was applied to illustrate relationship between several independent or predictor variables and a dependent or criterion variable. The Beta (standardized regression coefficients) value is a measure of how strongly each predictor variable influences the criterion variable. $p$-value $<0.05$ was considered as an entrance criterion, while $p>0.05$ was considered as removal criterion.

Receiver operating characteristics (ROC) curves were used. The area under the curve (AUC) can range from 0.5 to 1 and diagnostic test that approaches 1 indicates a perfect discriminator. ROC curves also determined the threshold value for optimal sensitivity and specificity, which was constructed by calculating the true positive fraction (sensitivity percent) and the false positive fraction (100-specificity) of markers at several cutoff points.

\section{Results}

In the present study both BMI and waist hip ratio (WHR) were significantly higher among obese subjects before diet (group II), obese subjects after diet (group III) and obese diabetics (group IV) compared to control group (group I), while there was a significant decrease in the mean level of BMI in group III compared to group II (Table 1).

The mean levels of total cholesterol, triglycerides and LDL cholesterol were significantly decreased meanwhile those of HDL cholesterol were significantly increased after weight loss (group 3) as compared to (group 2) (Table 1).

Table (1): Comparison between different study groups regarding Body mass index (BMI), Waist hip ratio (WHR) and Lipid profile.

\begin{tabular}{lllll}
\hline Variables & $\begin{array}{c}\text { Group I } \\
(\text { Control) } \\
\mathrm{n}=15\end{array}$ & $\begin{array}{c}\text { Group II } \\
\text { Obese (before diet) } \\
\mathrm{n}=15\end{array}$ & $\begin{array}{c}\text { Group III } \\
\text { Obese (after diet) } \\
\mathrm{n}=10\end{array}$ & $\begin{array}{c}\text { Group IV } \\
\text { Obese diabetics } \\
\mathrm{n}=15\end{array}$ \\
\hline Body mass index (BMI) & $22.2 \pm 1.89$ & $34.1 \pm 3.81 \mathbf{a}$ & $28.72 \pm 2.42 \mathbf{a b}$ & $35.26 \pm 2.28 \mathbf{a}$ \\
Waist hip ratio (WHR) & $0.78 \pm 0.07$ & $0.84 \pm 0.04 \mathbf{a}$ & $0.82 \pm 0.035^{\mathbf{a}}$ & $0.9 \pm 0.04 \mathbf{a}$ \\
Total cholesterol mg/dl & $156.47 \pm 18.23$ & $169.53 \pm 18.41$ & $155.9 \pm 14.38 \mathbf{b}$ & $205.4 \pm 15.87 \mathbf{a}$ \\
Triglycerides mg/dl & $50.73 \pm 13.32$ & $56 \pm 13.73$ & $50.1 \pm 5.13$ & $117 \pm 20 \mathbf{a}$ \\
HDL-cholesterol mg/dl & $73.13 \pm 7.56$ & $56.86 \pm 14.9 \mathbf{a}$ & $61.7 \pm 9.25 \mathbf{a}$ & $57.73 \pm 13.36^{\mathbf{a}}$ \\
LDL-cholesterol mg/dl & $69.4 \pm 14.93$ & $98.33 \pm 18.39 \mathbf{a}$ & $74.4 \pm 13.15^{\mathbf{b}}$ & $113.73 \pm 16.25^{\mathbf{a}}$ \\
\hline Values are mean $\pm \mathrm{SD}$ where, a: Significant compared to group I $(p<0.05)$. b: Significant compared to group II $(p<0.05)$.
\end{tabular}

The mean serum levels of fasting glucose and insulin together with Insulin resistance assessed using the homeostasis model assessment ratio (HOMA-IR) formula; were significantly higher in group II and group IV compared to control group. While the comparison between group II and group III revealed tendency to decrease in HOMA-IR after weight reduction but this tendency was statistically insignificant (Table 2).

As regard to leptin, its mean serum levels were significantly higher in the different studied groups compared with control group, while the mean serum levels of resistin were increased significantly in group II and group IV as compared to control group. On the other hand, the mean serum levels of adiponectin were decreased significantly in group II and group IV compared to control group (Table 2).

On comparing the effect of weight loss on the serum levels of the three hormones, a significant decrease was found in the mean levels of both 
resistin and leptin and a significant increase in the mean level of adiponectin on comparing obese (after diet) group with the obese (before diet) (Table 2).

Table (2): Comparison between different study groups according to fasting plasma glucose (FPG), serum insulin, insulin resistance, serum leptin, adiponectin and resistin levels.

\begin{tabular}{|c|c|c|c|c|}
\hline Variables & $\begin{array}{c}\text { Group I } \\
\text { (Control) }\end{array}$ & $\begin{array}{c}\text { Group II } \\
\text { Obese (before diet) }\end{array}$ & $\begin{array}{c}\text { Group III } \\
\text { Obese (after diet) }\end{array}$ & $\begin{array}{c}\text { Group IV } \\
\text { Obese diabetics }\end{array}$ \\
\hline Fasting plasma glucose $(\mathrm{mg} / \mathrm{dl})$ & $73.4 \pm 5.9$ & $81.9 \pm 10.3 \mathrm{a}$ & $77 \pm 6.5$ & $159.1 \pm 8.6^{\mathbf{a b}}$ \\
\hline Insulin ( & $10.54 \pm 1.45$ & $13.98 \pm 2.18^{\mathbf{a}}$ & $11.01 \pm 1.29$ & $17.15 \pm 2.01 \mathbf{a b}$ \\
\hline Insulin resistance & $1.91 \pm 0.64$ & $2.83 \pm 1.02^{\mathrm{a}}$ & $2.12 \pm 0.92$ & $7.39 \pm 1.21 \mathbf{a b}$ \\
\hline Leptin (ng/ml) & $13.51 \pm 2.95$ & $22.79 \pm 5.53 \mathrm{a}$ & $18.53 \pm 3.99 \mathbf{a b}$ & $22.23 \pm 4.98 \mathrm{a}$ \\
\hline Adiponectin (ng/ml) & $6.53 \pm 2.42$ & $3.79 \pm 1.80^{\mathrm{a}}$ & $5.65 \pm 1.45 \mathrm{~b}$ & $4.05 \pm 0.84^{\mathrm{a}}$ \\
\hline Resistin (ng/ml) & $4.22 \pm 1.67$ & $6.27 \pm 0.61^{\mathrm{a}}$ & $4.54 \pm 0.84 \mathbf{b}$ & $6.04 \pm 1.95^{\mathrm{a}}$ \\
\hline
\end{tabular}

In a stepwise multiple regression analysis model containing BMI and WHR in the different study groups to evaluate the factors affecting leptin, resistin and adiponectin, WHR was significantly found to be an independent factor affecting levels of both leptin and resistin in control group only which means that an increase in WHR causes an increase in levels of both leptin and resistin (Table 3 ), while (Table 4) revealed that upon applying the stepwise multiple regression analysis containing leptin, resistin and adiponectin to the different study groups for evaluation of the factors affecting insulin resistance, resistin was significantly found to be an independent factor affecting level of insulin resistance in obese diabetic group only, thus an increase in resistin level will subsequently cause an increase in insulin resistance.

Table (3): Stepwise multiple regression analysis for independent factors affecting the adipocytokines in control group.

\begin{tabular}{llccc}
\hline Hormone & Factors & $\beta$ & SE & $p$ \\
\hline Leptin $(\mathrm{ng} / \mathrm{ml})$ & Constant & 32.4 & 7.5 & 0.001 \\
& WHR & -24.2 & 9.5 & 0.025 \\
Resistin $(\mathrm{ng} / \mathrm{ml})$ & Constant & 13.7 & 4.4 & 0.008 \\
& WHR & -12.2 & 5.6 & 0.050 \\
\hline
\end{tabular}

Table (4): Stepwise multiple regression analysis for independent factors affecting insulin resistance in obese diabetic group.

\begin{tabular}{lllc}
\hline Factors & $\beta$ & SE & $p$ \\
\hline Constant & -2.3 & 3.8 & 0.554 \\
Resistin $\mathrm{ng} / \mathrm{ml}$ & 1.6 & 0.6 & 0.020 \\
\hline
\end{tabular}

Regarding the receiver operating characteristic curve (ROC) analysis to calculate the best cutoff point for Leptin, adiponectin and resistin that discriminates between control group and obese groups (obese before diet and obese diabetics) we found that the best cutoff point of leptin (17.95ng/ $\mathrm{ml}$ ) at which sensitivity $=76.67 \%$ (True positive), at absolute specificity (True negative). Area under the curve (AUC) $[\mathrm{SE}]=0.931[0.035], 95 \%$ confidence limits range $=0.862-1, p=0.0001$ (Fig. 1), while the best cutoff point of adiponectin was $(5.4 \mathrm{ng} / \mathrm{ml})$ at which sensitivity $=93.3 \%$, and specificity $=73.3 \%$, area under the curve (AUC) [SE] $=0.853[0.061], 95 \%$ confidence limits range $=$ $0.733-0.973, p=0.0001$ (Fig. 2). The best cutoff point of resistin was $(4 \mathrm{ng} / \mathrm{ml})$ at which sensitivity $=93.3 \%$, and specificity $=60 \%$, area under the curve (AUC) $[\mathrm{SE}]=0.811[0.076], 95 \%$ confidence limits range $=0.663-0.959, p=0.001$ (Fig. 3).

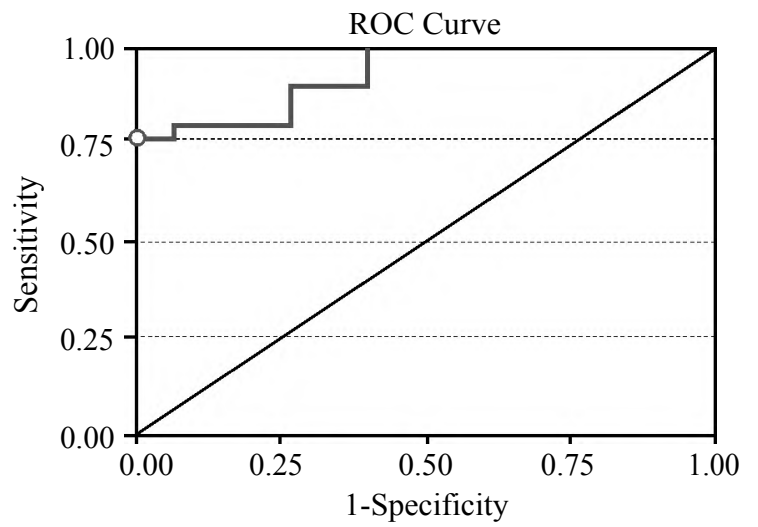

Fig. (1): Receiver operating characteristic curve (ROC) for detection of obesity by leptin.

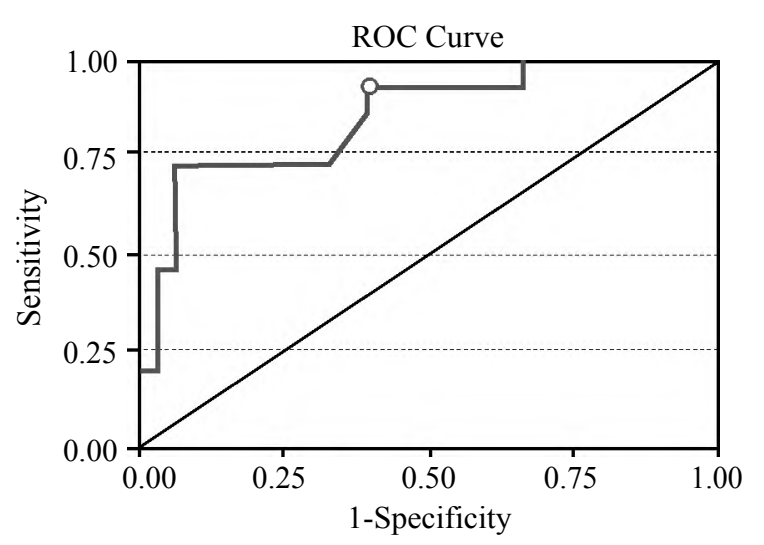

Fig. (2): Receiver operating characteristic curve (ROC) for detection of obesity by adiponectin. 


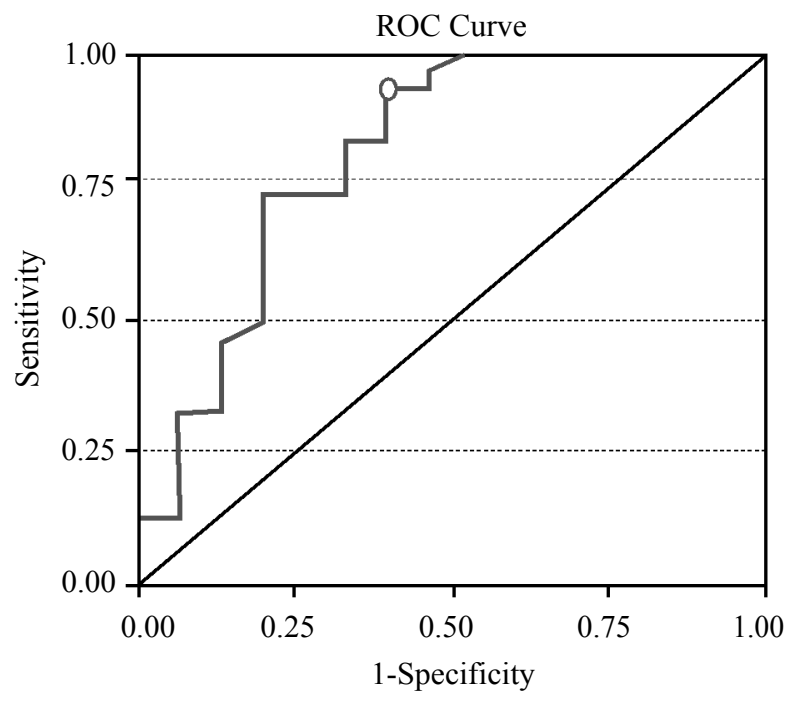

Fig. (3): Receiver operating characteristic curve (ROC) for detection of obesity by resistin.

Considering the percentage change in the mean serum levels of leptin, adiponectin and resistin in obese (after diet) group compared to obese (before diet) group, (Fig. 4) revealed that the mean serum level of adiponectin increased by $49.17 \%$, while the mean levels of leptin and resistin reported a decrease by $18.67 \%$ and $27.53 \%$ respectively. (Fig. 5) showed that there was a significant positive correlation between leptin and WHR in the different studied groups, and (Fig. 6) shows significant negative correlation between adiponectin and WHR, while (Fig. 7) shows significant positive correlation between resistin and insulin resistance in the different studied groups.

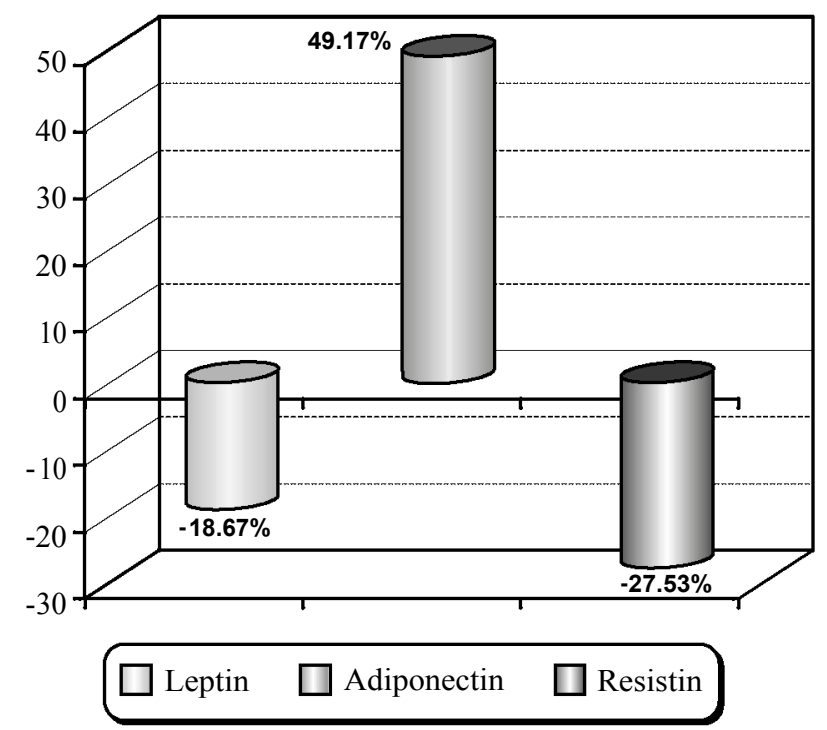

Fig. (4): Percentage change of leptin, adiponectin and resistin levels in obese (after diet) group compared to obese (before diet) group.

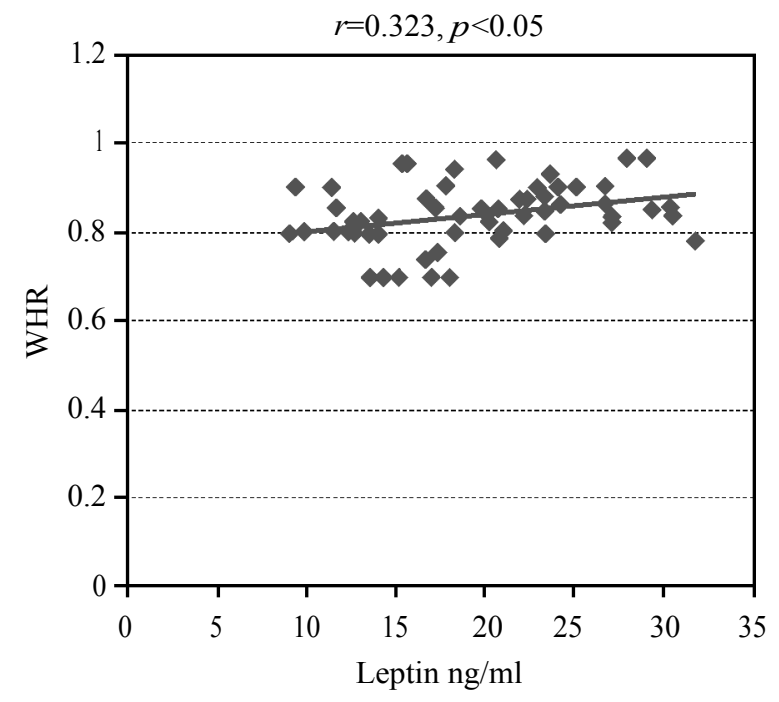

Fig. (5): Linear regression analysis of leptin $\mathrm{ng} / \mathrm{ml}$. and WHR in the different studied groups.

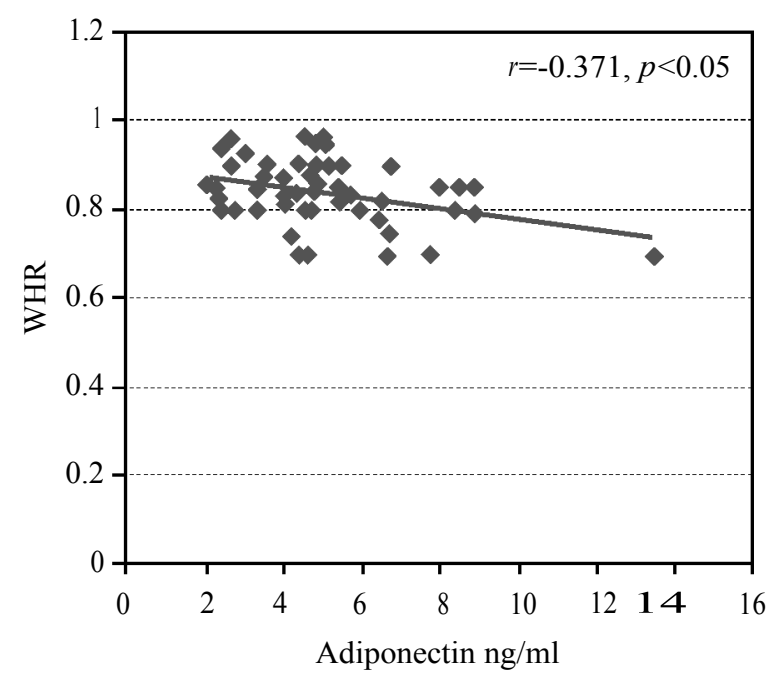

Fig. (6): Linear regression analysis of adiponectin $\mathrm{ng} / \mathrm{ml}$. and WHR in the different studied groups.

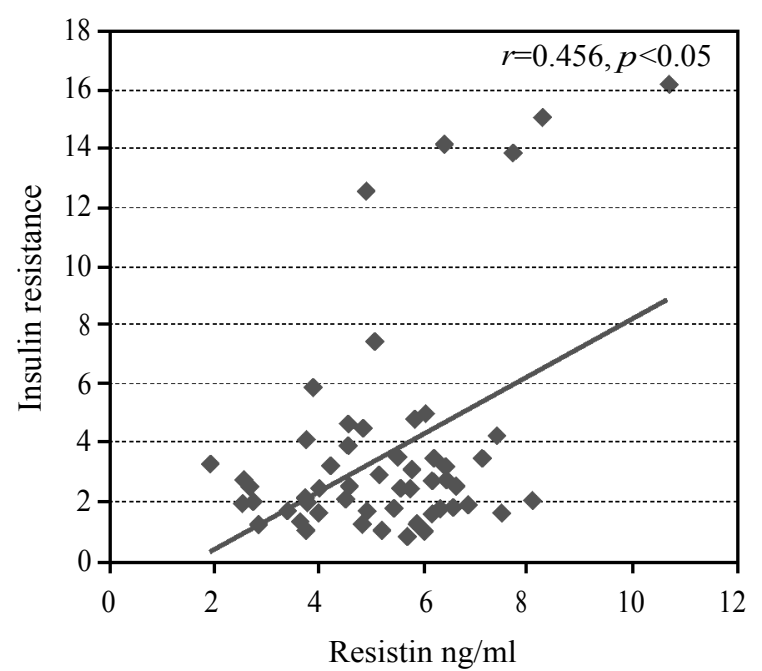

Fig. (7): Linear regression analysis of resistin $\mathrm{ng} / \mathrm{ml}$. and insulin resistance in the different studied groups. 


\section{Discussion}

Obesity is a global epidemic triggering significant morbidity and mortality rate [30]. Many studies had indicated that adipose tissue has an endocrine function secreting bioactive substances known as adipokines. Alteration in specific adipokine profile lead to metabolic disturbances that play a central role in the development of type 2 DM [31].

In this work we studied the change of leptin, adiponectin and resistin levels in normal, obese and obese diabetics as well as the effect of weight loss on mentioned adipokines. Our results showed that the mean serum level of leptin was significantly higher in both obese before diet group as well as in the obese diabetic group and that it had been significantly decreased after weight loss. Consistent with our findings Jung et al., [32] found that the mean level of leptin had significantly decreased in parallel with weight loss. In the same line with our results Al-Harithy, [33] reported that leptin is detectable in human serum and its circulating level was found to be elevated in proportion to the degree of obesity.

Previous studies $[\mathbf{3 2 , 3 4 , 3 5 ]}$ proved that leptin levels rapidly decline with caloric restriction. However, the notion of leptin as an anti-obesity hormone was called into question because the "common" form of obesity is typically associated with high leptin levels (that reflect high energy stores) and leptin resistance [36]. These findings could be explained on bases that although most obese humans have an elevated circulating level of leptin, they do not respond to this increased endogenous leptin level by reducing their food intake due to leptin resistance [37]. Leptin resistance may be explained by defective transport of leptin across the blood-brain barrier and impaired signaling in neurons and other target cells. Other mechanism is that leptin resistance may be due to a defect in the leptin-receptor gene that results in the absence of portions of its cytoplasmic region. Therefore, individuals with this mutation tend to have excessive food intake and weight gain [38] .

In the current study we have found no significant relation between leptin and insulin resistance. Our results were confirmed by others $[39,40]$. In contrast to studies that had indicated a relationship between leptin levels and insulin resistance due to increased fat mass. Other investigators have demonstrated both in experimental animals and human subjects that the association between insulin resistance and leptin levels may be independent of body fat mass [41]
Adiponectin is mostly expressed in subcutaneous adipose tissue, interestingly, although adiponectin is secreted by mature adipocytes, its plasma level shows a negative correlation with body fat mass [42]. It has been found that adiponectin plasma level in obese individuals was lower than in nonobese. One has accordingly suggested that adiponectin plays an important role in the regulation of insulin resistance, glucose and lipid homeostasis [43]. In the present study, the mean serum level of adiponectin was significantly decreased in obese and obese diabetic subjects as compared to controls.

Moreover, weight loss and decrease in BMI in the obese group subjects were accompanied by a significant increase in the level of serum adiponectin. Our findings could be explained on bases that adiponectin has an anti-obesity effect due to increased energy expenditure and impaired adipocyte differentiation [44]. While Meyer et al., [2] suggested that another possible contributor to obesity related reductions in adiponectin may be dysfunctional Subcutaneous adipose tissue (SAT). Our current study shows that despite an obesity associated reduction in adiponectin secretion, SAT still secretes and contributes more significantly to serum adiponectin than does visceral adipose tissue (VAT). Because of its larger mass and greater secretion rate, even small reductions in adiponectin production by SAT have the potential to significantly lower circulating levels of adiponectin. These results were supported by $[\mathbf{3 2 , 4 1 , 4 5 , 4 6 ]}$

In the present study the mean serum level of adiponectin showed tendency to decrease with the decrease in both fasting serum insulin and HOMAIR levels though this tendency to decrease was insignificant. Since our study had a relatively small number of subjects it is possible that with a larger number of subjects the correlation between adiponectin and insulin resistance may have achieved a statistical significance.

In addition, Acharya [47] found that improvement in insulin sensitivity was not related to adiponectin levels in the intervention and the control groups among adults with impaired glucose tolerance. These findings can be partly explained by differences in either the baseline degree of insulin resistance, adiponectin levels and/or the improvement in insulin resistance and adiponectin levels after each intervention. Also have suggested that the improved insulin sensitivity induced by changes in adiponectin levels may not result from a short term intervention.

Moreover, we found that the mean serum level of adiponectin was significantly lower in the obese 
diabetic group as compared to control group. Similarly, an inverse association between adiponectin levels and the risk for diabetes was reported among a large population of healthy women [48] and a middle-aged population cohort [49]. These findings suggested that an increase in adiponectin levels may contribute to improved insulin sensitivity and may provide a molecular link between adiposity and diabetes [50]. Whereas a number of studies in obese and obese diabetic subjects showed negative association of insulin resistance and adiponectin, some others didn't show so. Our results were supported by Snehalatha et al., [51] who stated that insulin resistance and adiponectin were not directly associated either in the youth or in healthy adults supports our observations. Anyhow, the relation between insulin and adiponectin remains rather controversial, particularly concerning how or ifthey regulate each other [52].

In our study there was no significant correlation between adiponectin and insulin levels. This observation agreed with the results found by $[41,53]$ and in contrast with findings from some, studies which showed that adiponectin serum level correlates negatively with insulin resistance $[\mathbf{3 7 , 4 5 , 5 4 ]}$.

This study proved a significant negative correlation between adiponectin serum level and WHR which expresses visceral obesity. Our results are highly supported by Matsuzawa [55] who stated that negative correlation of adiponectin levels and visceral adiposity is stronger than between adiponectin levels and subcutaneous adiposity. This could be explained on the bases that inhibiting factors for adiponectin synthesis or secretion are secreted from visceral adipose tissue.

Resistin is another adipokine that was identified in mouse and in human fat cells. It was suggested that resistin might link obesity with insulin resistance and diabetes [45]. Our results revealed a significant elevation in the mean serum level of resistin in the obese before diet and the obese diabetic subjects as compared to controls. A significant decrease in the mean serum level of resistin has been observed after weight reduction. Moreover, a significant positive correlation between resistin level and both BMI and WHR was also detected.

Several studies support the positive relationship between insulin resistance and elevated plasma resistin levels in obese and type 2 diabetic individuals [56], whereas other studies have shown contradictory findings [57]. Beside its role in obesity and insulin resistance, resistin is greatly implicated in proinflammatory processes which are causally involved in the development of insulin resistance in both rodents and humans [58]. Resistin regulates the production of key pro-inflammatory cytokines, such as TNFa and IL6, through the activation of $\mathrm{NF}-\mathrm{kB}$ signaling pathways in macrophages contributing to profound alterations of peripheral insulin signaling pathways resulting in an insulinresistant state [59].

The majority of the resistin expression and secretion from adipose tissue is found in stromal vascular fraction including undifferentiated preadipocytes, vascular endothelial and smooth muscle cells, and in some cases immune system cells such as monocytes and macrophages [60]

The expression of resistin in humans by macrophages versus adipocytes is particularly interesting given that obese subjects are known to have greater infiltration of macrophages into their adipose tissue [61]. Our findings are in agreement with $[32,62,63]$ as they reported higher levels of serum resistin in obese subjects than normal weight subjects. In the same line Jung et al., [32] also found that modest weight loss is associated with a reduction in serum resistin level. Moreover, Savage et al., [64] reported greater resistin mRNA in the adipose tissue of morbidly obese individuals.

The current study showed that the mean serum resistin level positively correlated with fasting plasma glucose level, serum insulin level and insulin resistance as determined by homeostasis model assessment of insulin resistance (HOMAIR). Shen et al., [65] explained that the human resistin may interfere with insulin signaling by stimulating the expression of phosphatase and tensin homolog deleted on chromosome ten (PTEN), which dephosphorylates 3-phosphorylated phosphoinositide (PIP3). This leads to the decrease in PDK and Akt phosphorylation observed in these cells when exposed to resistin. Another possible mechanism is that resistin inhibited adipocyte differentiation by $80 \%$ in Three T3L1 cells [66]

This suggests that resistin may promote insulin resistance by increasing the storage of triglycerides in muscle and liver instead of adipose tissue. Indeed, failure of adipocyte differentiation has been proposed as a cause of type 2 diabetes, possibly through an ectopic overload of fatty acids and lipotoxicity of non-adipose tissue $[67,68]$. Comparable findings were also obtained by $[41,69,70]$. On contrary Heilbronn et al., [71] failed to detect any association between resistin concentration and markers for insulin sensitivity. These observations 
suggest that the role of resistin in the pathogenesis of diabetes remains controversial [69].

In our work, in a stepwise linear regression model contained leptin, resistin and adiponectin applied to the different study groups to evaluate factors affecting insulin resistance, resistin was significantly found to be an independent factor affecting the level of insulin resistance in obese diabetic group. Unlike resistin and leptin mean adiponectin level showed significant decrease in the obese before diet and obese diabetic groups compared to controls. Also, significant increase in its mean level by $49.17 \%$ was noticed in the present work after following exercise and diet regimen.

In the current work the diagnostic utility of the adipocytokines was determined by measures of ROC curve analysis. We demonstrated that elevation of resistin and leptin and decrease in adiponectin levels were useful markers to differentiate between obese and non-obese subjects due to their high sensitivity $(93.3 \%, 86.7 \%, 86.7 \%)$ and high specificity $(80 \%, 93 \%$ and $73 \%)$ respectively. Zhuo et al., [72] found that leptin/adiponectin had a better ability to differentiate individuals with metabolic syndrome (high sensitivity, specificity and AUC value) than for either leptin or adiponectin alone.

In agreement with our results Hulver et al., [73] demonstrated that exercise training-induced enhancement of insulin sensitivity was not accompanied by changes in adiponectin levels. Moreover, Hansen et al., [39] who concluded that alterations in plasma leptin levels in obese type 2 diabetes patients are attributed to the greater adipose tissue mass, and not necessarily to the presence of the type 2 diabetic state.

In conclusion, our data clearly demonstrated that insulin resistance is more tightly correlated with circulating resistin. Resistin rather than adiponectin and leptin appeared to be more important determinant of insulin resistance.

\section{References}

1- SALIHU H.M., BONNEMA S.M. and ALIO A.P.: Obesity: What is an elderly population growing into? Maturitas, 63: 7-12, 2009.

2- MEYER L.K., CIARALDI1 T.P., HENRY R.R., WITTGROVE A.C., and PHILLIPS S.A.: Adipose tissue depot and cell size dependency of adiponectin synthesis and secretion in human obesity. Adipocyte, 2 (4): 217-226, 2013.

3- QADIR M.I. and AHMED Z.: Lep Expression and its role in obesity and type-2 diabetes. Crit. Rev. Eukaryot Gene Expr., 27 (1): 47-51, 2017.
4- KOCOT J., DZIEMIDOK P., KIEĹCZYKOWSKA M., HORDYJEWSKA A., SZCZES NIAK G. and MUSIK I.: Adipokine Profile in Patients with Type 2 Diabetes Depends on Degree of Obesity. Med. Sci/ Monit., 23: 4995 5004, 2017.

5- PAPAETIS G.S., PAPAKYRIAKOU P. and PANAGIOTOU T.N.: Central obesity, type 2 diabetes and insulin: exploring a pathway full of thorns. Arch. Med. Sci., Jun., 19; 11 (3): 463-482, 2015.

6- PICU A., PETCU L., ŞTEFAN S., et al.: Markers of oxidative stress and antioxidant defense in romanian patients with type 2 diabetes mellitus and obesity. Molecules, 22 (5): E714, 2017.

7- DAS P., BHATTACHARJEE D., BANDYOPADHYAY S.K., BHATTACHARYA G. and SINGH R.: Association of obesity and leptin with insulin resistance in type 2 diabetes mellitus in indian population. Indian J. Physiol. Pharmacol., 57 (1): 45-50, 2013.

8- NIU M., XIANG L., LIU Y., et al.: Adiponectin induced AMPK impairment mediates insulin resistance in bama mini-pig fed high-fat and high-sucrose diet. AsianAustralas J. Anim. Sci., 2017.

9- GOMES B.F. and ACCARDO C.M.: Immunoinflammatory mediators in the pathogenesis of diabetes mellitus. Einstein (São Paulo), 17 (1): 1-5, 2019.

10- STEPIEN M., ROSNIAK-BAK K., PARADOWSKI M., et al.: Waist circumference, ghrelin and selected adipose tissue-derived adipokines as predictors of insulin resistance in obese patients: Preliminary results. Med. Sci. Monit., 17 (11): PR13-18, 2011.

11-REINEHR T., WOELFLE J., WIEGAND S., et al.: Leptin but not adiponectin is related to type 2 diabetes mellitus in obese adolescents. Pediatr Diabetes, 17 (4): 281-88, 2016.

12- LEE Y.H. and SONG G.G.: Association of circulating resistin, leptin, adiponectin and visfatin levels with Behçet disease: A meta-analysis. Clin. Exp. Dermatol. Jul., 43 (5): 536-545, 2018

13- KHALILI S., NURI R., MOGHADASSI M. and MOGHARNASI M.: Leptin and Insulin Resistance in Young Adult Obese Females: Effect of Eight Weeks Resistance Training. Research in Endocrinology, Article ID 665365, DOI: 10.5171/2014.665365, 2014.

14- MUSIL F., BLAHA V., TICHA A., HYSPLER R., HALUZIK M., LESNA J., et al.: Effects of body weight reduction on plasma leptin and adiponectin/leptin ratio in obese patients with type 1 diabetes mellitus. Physiol. Res., 64 (2): 221-228, 2015.

15- BRICHARD S.M., DELPORTE M.L. and LAMBERT M.: Adipocytokines in anorexia nervosa: A review focusing on leptin and adiponectin. Horm. Metab Res., 35: 337342,2003

16- OUCHI N. and WALSH K: Adiponectin as an antiinflammatory factor. Clin. Chim. Acta., 380: 24-30, 2007.

17- STEPPAN C.M., BROWN E.J., WRIGHT C.M., BHAT S., BANERJEE R.R., DAI C.Y., et al.: Family of tissuespecific resistin-like molecules. Proc. Natl. Acad. Sci. USA, 98: 502-506, 2001.

18- TAKEISHI Y.: Resistin is A Novel Biomarker For a Risk of Heart Failure. J. Cardiovasc. Dis. Diagn., 1-4, 2013. 
19- HUANG X. and YANG Z.: Resistin's, obesity and insulin resistance: the continuing disconnect between rodents and humans. J Endocrinol Invest. Jun., 39 (6): 607-15, 2016.

20- TRINDER P.: Enzymatic methods for glucose determination. Ann. Clin. Biochem., 6: 24-26, 1969.

21- JUDZEWITSCH R.G., PFEIFER M.A., BEST J.D., et al.: Chronic Chlorpropamide therapy of non-insulindependent diabetes augments basal and stimulated insulin secretion by increasing islet sensitivity to glucose. J. Clin. End. and Metab., 55 (2): 321-332, 1982.

22- CONSIDINE R.V., SINHA M.K., HEIMAN M.L., et al.: Serum immunoreactive-leptin concentrations in normal weight and obese humans. N. Engl. J. Med., 334: 292295, 1996.

23- WATANABE S., OKURA T. and KURATA M.: The effect of losartan and amlodipine on serum adiponectin in Japanese adults with essential hypertension. Clin. Ther., 28: 1677-1685, 2006.

24- PILZ S., HOREJSI R., MOLLER R., et al.: Early atherosclerosis in obese juveniles is associated with low serum levels of adiponectin. J. Clin. Endocrinol. Metab., 90 (8): 4792-4796, 2005.

25- MATHEWS D.R., HOSKER J.P., RUDENSKI A.S., et al.: Homeostasis model assessment: insulin resistance and beta-cell function from fasting plasma glucose and insulin concentration in man. Diabetolgia, 28: 412-419, 1985.

26- FLEGG: An investigation of determination of serum cholesterol by an enzymatic method. Ann. Clin. Biochem., 10: 79-84, 1973.

27- IZZO C.,GRILLO F. and MURADOR E.: Improved method for determination of high-density- lipoprotein cholesterol I. Isolation of high-density lipoprotein by use of polyethylene glycol 6000 Clin. Chem., 27 (3): 371374, 1981.

28- FOSSATI and LORENZO: Serum Triglycerides determined colorimetericallly with an enzyme that produces hydrogen peroxide, Clin. Chem., 128: 2077-2080, 1982.

29- FRIEDEWALD W.T., LEVY R.I. and FREDRICKSON D.S.: Estimation of the concentration of LDL cholesterol in plasma without use of the preparative ultracentrifuge. Clin. Chem., 18: 499, 1973.

30- HEINDEL J.J.: Endocrine disruptors and the obesity epidemic. Toxicol. Sci., 76: 247-9, 2003.

31- PEREIRA S.S. and ALVAREZ-LEITE J.I.: Adipokines: Biological functions and metabolically healthy obese profile. J. Recept Ligand Channel Res., 7: 1-11, 2014.

32- JUNG S.H., PARK H.S., KIM K., CHOI W., AHN C.W., KIM B.T., KIM S.M., LEE S.Y., AHN S.M., KIM Y.K., KIM H.J., KIM D.J. and LEE K-W.: Effect of weight loss on some serum cytokines in human obesity: increase in IL-10 after weight loss. Journal of Nutritional Biochemistry, 19 (Suppl 6): 371-5, 2008.

33- AL-HARITHY R.N.: Strong association between serum levels of leptin and resistin in non-diabetic Saudi adult women. Kuwait Medical Journal, 39 (Suppl 1): 31-35, 2007.
34- KERSHAW E.E. and FLIER J.: Adipose tissue as an endocrine organ. J. Clin. Endocrinol. Metab., 89: 254856, 2004.

35- VENDRELL J., BROCH M., VILARRASA N., MOLINA A., GÓMEZ J.M., GUTIÉRREZ C., SIMÓN I., SOLER J. and RICHART C.: Resistin, adiponectin, ghrelin, leptin, and proinflammatory cytokines: Relationships in obesity. Obes. Res., 12 (Suppl 6): 962-71, 2004.

36- AHIMA R.S.: Revising leptin's role in obesity and weight loss. J.C. Invest, 118: 2380-83, 2008.

37- KOERNER A., KRATZSCH J. and KIESS W.: Adipocytokines: leptin - the classical, resistin - the controversial, adiponectin - the promising, and more to come. Best Practice and Research Clinical Endocrinology and Metabolism, 19: 525-46, 2005.

38- ETEMAD A., RAMACHANDRAN V., PISHVA S.R., et al.: Analysis of Gln223Agr polymorphism of leptin receptor gene in type II diabetic mellitus subjects among Malaysians. Int. J. Mol. Sci., 14 (9): 19230-19244, 2013.

39- HANSEN D., DENDALE P., BEELEN M., JONKERS R.A.M., MULLENS A., CORLUY L., MEEUSEN R. and VAN LOON L.J.C.: Plasma adipokine and inflammatory marker concentrations are altered in obese, as opposed to non-obese, type 2 diabetes patients. Eur. J. Appl. Phisiol., 109: 397-04, 2010.

40- De LUIS D.A., ALLER R., IZAOLA O. and OVALLE H.F.: The serum profile of adipokines in naïve patients with diabetes mellitus type 2 and obesity. J. Clin. Lab. Anal., 25 (Suppl 6): 409-13, 2011.

41- SILHA J.V., KRSEK M., SKRHA J.V., SUCHARDA P., NYOMBA B.L. and MURPHY L.J.: Plasma resistin, adiponectin and leptin levels in lean and obese subjects: Correlations with insulin resistance. Eur. J. Endocrinol., 149: 331-35, 2003.

42- ARITA Y., KIHARA S., OUCHI N., TAKAHASHI M., MAEDA K., MIYAGAWA J. and MATSUZAWA Y.: Paradoxical decrease of an adipose-specific protein, adiponectin, in obesity Biochem. Biophys. Res. Commun., 425: pp. 560-564, 2012.

43- SHAND B.I., SCOTT R.S., ELDER P.A. and GEORGE P.M.: Plasma adiponectin in overweight, nondiabetic individuals with or without insulin resistance. Diabetes Obes. Metab., 5 (Suppl 5): 349-53, 2003.

44- BAUCHE I.B., EL MKADEM S.A., POTTIER A.M., SENOU M., MANY M.C., REZSOHAZY R., PENICAUD L., MAEDA N., FUNAHASHI T. and BRICHARD S.M.: Overexpression of adiponectin targeted to adipose tissue in transgenic mice: Impaired adipocyte differentiation. Endocrinology, 148-54, 2007.

45- GOKALP D., BAHCECI M., OZMEN S., ARIKAN S., TUZCU A. and DANiS R.: Adipocyte volumes and levels of adipokines in diabetes and obesity. Diabetes and Metabolic Syndrome: Clinical Research and Reviews, 2: 253$58,2008$.

46- ABELGADIR M., KARLSSON A.F., BERGLUND L. and BERNE C.: Low serum adiponectin concentrations are associated with insulin sensitivity independent of obesity in Sudanese subjects with type 2 diabetes Mellitus. Diabetology \& Metabolic Syndrome, 5-15, 2013.

47- ACHARYA S.D.: Relationships between diet, weight loss, insulin resistance and adiponectin levels among 
overweight/obese adults. Doctoral Dissertation, University of Pittsburgh, 2011.

48- HEIDEMANN C., SUN Q., VAN DAM R.M., MEIGS J.B., ZHANG C., TWOROGER S.S., MANTZOROS C.S. and HU F.B.: Total and high-molecular-weight adiponectin and resistin in relation to the risk for type 2 diabetes in women. Ann. Intern. Med., 149 (Suppl 5): 307-16, 2008.

49- SALTEVO J., LAAKSO M., JOKELAINEN J., KEINANEN-KIUKAANNIEMI S., KUMPUSALO E. and VANHALA M.: Levels of adiponectin, C-reactive protein and interleukin-1 receptor antagonist are associated with insulin sensitivity: A population-based study. Diabetes Metab. Res. Rev., 24 (Suppl 5): 378-83, 2008.

50- AWAZAWA M., UEKI K., INABE K., YAMAUCHI T., KUBOTA N., KANEKO K., KOBAYACHI M., IWANE A., SASAKO T., OKAZAKI Y., OHSUGI M., TAKAMATO I., YAMASHITA S., ASAHARA H., AKIRA S., KASUGA M. and KADOWAKI T.: Adiponectin Enhances Insulin Sensitivity by Increasing Hepatic IRS-2 Expression via a Macrophage-Derived IL-6-Dependent Pathway. Cell Metabolism, 13 (Suppl 4): 401-12, 2011.

51- SNEHALATHA D., YAMUNA A. and RAMACHANDRAN A.: Plasma adiponectin does not correlate with insulin resistance and cardiometabolic variables in nondiabetic asian indian teenagers. Diabetes Care, , 31: 237479, 2008.

52- ANNUZZI G., BOZZETTO L., PATTI L, SANTANGELO C., GIACCO R. and DI MARINO L.: Type 2 diabetes mellitus is characterized by reduced adiponectin response: a possible link with diabetic postprandial dyslilpidemia. Metabolism Clinical and Experimental, 59: 567-74, 2010.

53- BEHRE C.J., GUMMESSON A., JERNÅS M., LYSTIG T.C., FAGERBERG B., CARLSSON B. and CARLSSON L.M.: Dissociation between adipose tissue expression and serum levels of adiponectin during and after diet-induced weight loss in obese subjects with and without the metabolic syndrome. Metabolism, 56: 1022-28, 2007.

54- IZADI M., GOODARZI M.T., KHALAJ H.S., KHORSHIDI D. and DOALI H.: Serum Adiponectin Levels are Inversely Correlated with Insulin Resistance in Obese Men with Type 2 Diabetes. International Journal of Endocrinology and Metabolism, 9: 253-57, 2011.

55- MATSUZAWA Y.: The metabolic syndrome and adipocytokines. FEBS Letters, 580: 2917-21, 2006.

56- MENZAGHI C., COCO A., SALVEMINI L., THOMPSON R., DE COSMO S., DORIA A., et al.: Heritability of serum resistin and its genetic correlation with insulin resistance-related features in nondiabetic Caucasians. J. Clin. Endocrinol. Metab., 91: 2792-5, 2006.

57- MOSTAFAZADEH M., HAIATY S., RASTQAR A. and KESHVARI M.: Correlation between resistin level and metabolic syndrome component: A review. Horm. Metab. Res., 50: 521-36, 2018.

58- PINE G.M., BATUGEDARA H.M. and NAIR M.G.: Here, there and everywhere: resistin like molecules in infection, inflammation, and metabolic disorders. Cytokine, 110: 442-51, 2018

59- AL HANNAN F. and CULLIGAN K.G.: Human resistin and the RELM of Inflammation in diabesity. Diabetol. Metab. Syndr., 7: 54, 2015.

60- BARNES K.M. and MINER J.L.: Role of Resistin in
Insulin Sensitivity in Rodents and Humans. Current Protein and Peptide Science, 10 (Suppl 1): 96-107, 2009.

61- WEISBERG S.P., McCANN D., DESAI M., ROSENBAUM M., LEIBEL R.L. and FERRANTE Jr A.W.: Obesity is associated with macrophage accumulation in adipose tissue. J. Clin. Invest., 112: 1796-08, 2003.

62- DEGAWA-YAMAUCHI M., BOVENKERK J.E., JULIAR B.E., WATSON W., KERR K. and JONES R.: Serum resistin (FIZZ3) protein is increased in obese humans. J. Clin. Endocrinol. Metab., 88: 5452-55, 2003.

63- OWECKI M., MICZKE A., NIKISCH E., PUPEKMUSIALIK D. and SOWIN'SKI J.: Serum resistin concentrations are higher in human obesity but independent from insulin resistance. Exp. Clin. Endocrinol. Diabetes, 119 (Suppl 2): 117-21, 2011.

64- SAVAGE D.B., SEWTER C.P. and KLENK E.S.: Resistin/ Fizz3 expression in relation to obesity and peroxisome proliferator-activated receptor- $\{$ gamma $\}$ action in humans. Diabetes, 50: 2199-2202, 2001.

65- SHEN Y.H., ZHANG L., GAN Y., WANG X., WANG J., LeMAIRE S.A., COSELLI J.S. and WANG X.L.: Upregulation of PTEN (Phosphatase and Tensin Homolog Deleted on Chromosome Ten) Mediates p38 MAPK Stress Signal-induced Inhibition of Insulin Signaling. J. Biol. Chem., 281: 7727-36, 2006.

66- KIM K.H., LEE K. and MOON Y.S.: Cysteine-rich adipose tissue-specific secretory factor inhibits adipocyte differentiation. J. Biol. Chem., 276: 11252-11256, 2001.

67- DANFORTH E.: Failure of adipocyte differentiation causes type II diabetes mellitus? Nat. Genet., 26: 13, 2000.

68- McGARRY J.D.: Dysregulation of fatty acid metabolism in the etiology of type 2 diabetes. Diabetes, 51: 17-18: 2002.

69- GHARIBEH M.Y., AL TAWALLBEH G.M., ABBOUD M.M., RADAIDEH A., ALHADER A.A. and KHABOUR O.F. : Correlation of plasma resistin with obesity and insulin resistance in type 2 diabetic patients. Diabetes Metab, 36 (6 Suppl 1): 443-9, 2010.

70- GAZBAR S., FETHI B.S., ABDELMAGID T. , CHIHEB B.R. and OMRANE B: Relationship between OxidizedLDL and Resistin Levels in Obese Diabetic Subjects. Journal of Basic and Applied Scientific Research, 3 (Suppl 4): 313-17, 2013

71- HEILBRONN L.K., R.J., JANDEROVA L., ALBU J.B. KELLEY D.E., RAVUSSIN E. and SMITH S.R.: Relationship between Serum Resistin Concentrations and insulin resistance in nonobese, obese, and obese diabetic Subjects. The Journal of Clinical Endocrinology \& Metabolism, 89 (Suppl 4): 1844-48, 2004.

72- ZHUO Q1, WANG Z., FU P., PIAO J., TIAN Y., XU J. and YANG X.: Comparison of adiponectin, leptin and leptin to adiponectin ratio as diagnostic marker for metabolic syndrome in older adults of Chinese major cities. Diabetes Res. Clin. Pract., 84 (Suppl 1): 27-33, 2009.

73- HULVER M.W., ZHENG D., TANNER C.J. , HOUMARD J.A., KRAUS W.E. and SLENTZ C.A.: Adiponectin is not altered with exercise training despite enhanced insulin action. American Journal of Physiology. Endocrinology and Metabolism, 283: 861-65, 2002. 


\section{العلاقة بين الريسيستين والليبتين والديبونكتين الدين مع السمنة والسكرى من النوع الثين والثينى}

تعد السمنة من الأمراض الثائعة فى الدول الناية كما ثبت ارتباطها بالعديد مثل مرض السكرى وارتفاع ضغط الدم وأمراض القلب.

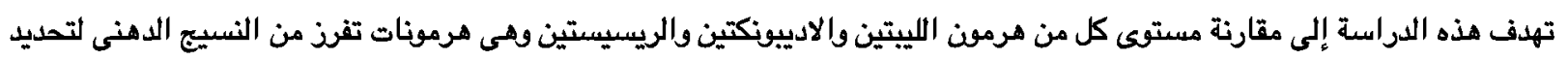

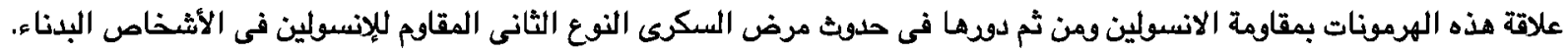
اشتملت هذه الدراسة على عدد هع من الاناث اللائى تتراوح أعمارهن من \/ اله ع عاماً وتم تقسيمهم إلى ع مجموعات بحثية كالأتى:

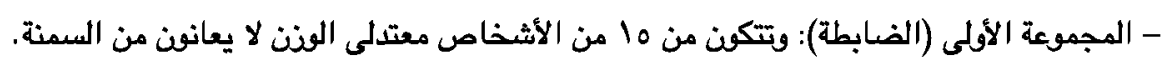

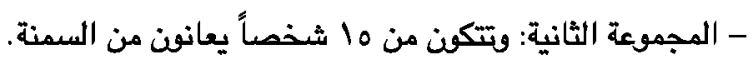

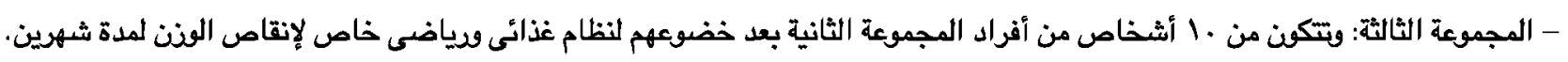

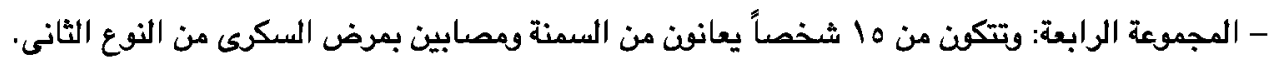

تم قياس مستوى الليتين والاديبونكتين والريسيستين فى مصل الدم باستخدام طريقة الاليزا وتم قياس مستوى الدهون عن طريق القياس

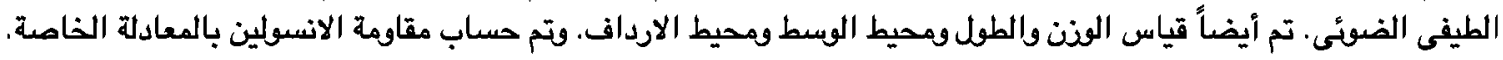
أسفرت الدراسة عن النتائج الآتية:

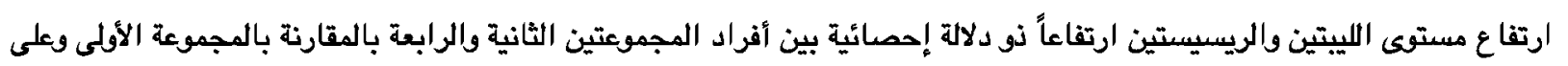
العكس كانت نتائج الاديونكتين فى نفس هاتين اليتين الجمونتين. وجد ارتباط طردى ذو دلالة إحصائية بين الليتين وكل من (معامل كتلة الجسم، نسبة الوسط للأرداف، والكوليسترول منففض الكئن الكثافة)

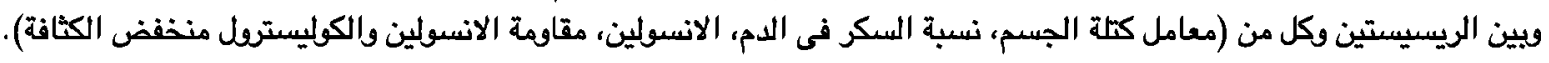

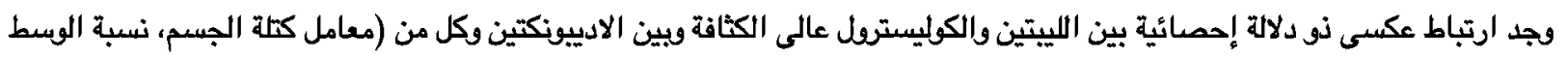

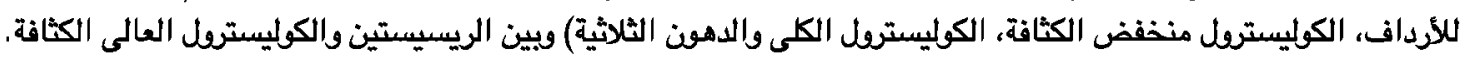
وتخلص هذه الدراسة إلى أن إنقاص الونن حتى لو بصورة معتدلة يمكن ان يحسن عوامل الخطوة الايضية عن طريق التغيير فى بعض السيتوكينات. 